\title{
Determinants of maize seed income and adoption of foundation seed production: evidence from Palpa District of Nepal
}

\author{
Mahesh Sapkota ${ }^{1 *}$, Niraj Prakash Joshi ${ }^{2}$, Rishi Ram Kattel ${ }^{3}$ and Mahima Bajracharya ${ }^{4}$
}

\begin{abstract}
Background: Maize is the second most important staple crop in terms of area and production in Nepal. The production and yield of maize are low in Nepal as compared to other similar agro-climatic regions. Seed is considered as a vital input in production. The yield of maize can be increased by using improved seeds and technologies. Farmers were generating good income being involved in foundation seed production as compared to certified seed. The maize seed sector in Nepal is handicapped by low domestic research and production capacity, which results in the poor supply of breeder and foundation seed for its multiplication. Hence, this study is aimed to investigate determinants of income from maize seed and adoption of foundation seed production in Palpa District of Nepal.
\end{abstract}

Methods: Palpa District of Nepal was selected for the study because of its high contribution on maize seed production. The sample size was determined using the software Raosoft. A total of 182 samples were selected using simple random sampling technique. Descriptive statistics, probit model, income regression model and the instrumental variable model were used to analyze data.

Results: The per hectare income from foundation seed production was higher than that from certified seed by NRs. 51,541 . The study revealed that schooling year of household head, family type, active members, farm category, total income from maize seed production and training received had statistically significant effect on the adoption of foundation seed production. It was found that income increased by about $44 \%$ for the households producing foundation seed as compared to certified seed. This higher income is mainly driven by the higher yield as well as the higher price of the foundation seed. The study revealed that increase in area under maize seed by one hectare would increase the income by $242 \%$. A result of the instrumental variable model showed that foundation seed production and extension services received do not affect significantly on maize seed income.

Conclusion: This study identified that foundation seed production was profitable farm business in Palpa District of Nepal. However, very few farmers adopted such technology due to lack of proper training and extension services.

Farmers should focus to increase area under foundation seed production to achieve higher returns.

Keywords: Adoption, Foundation seed, Instrumental variable, Maize, Probit

\section{Background}

Nepal's agriculture sector contributes about $28.79 \%$ to the national Gross Domestic Product (GDP). The share of cereal crops to Agriculture GDP is about 49\%, and

\footnotetext{
*Correspondence: sapkotamahes@gmail.com

${ }^{1}$ Nepal Agricultural Research Council, Communication, Publication and Documentation Division, Pilot Program for Climate Resilience, Khumaltar, Lalitpur, Nepal

Full list of author information is available at the end of the article
}

maize alone contributes about 7\% to AGDP [1]. Maize (Zea mays L.), important cereal crop, is ranked at second after paddy in terms of area and production in Nepal. The area, production and yield of maize in Nepal are 882,395 hectare (ha), 2,145,291 metric tonnes (Mt) and $2.43 \mathrm{Mt} / \mathrm{ha}$, respectively [2]. The maize crop, which comprises about $78 \%$ area out of total cultivated area in the hills, is one of the principal and staple foods for the midhill regions of the country mainly among poorer families 
and disadvantaged groups $[3,4]$. Two-third of the maize produced in the hills of Nepal is consumed directly by the farmers.

Seed is recognized as a vital element in boosting agricultural production by agricultural scientists, farmers and development workers [5]. It is considered as essential, strategic and relatively inexpensive input that determines the crop yields [6]. It also governs new innovations based on agriculture [7]. The seed sector in Nepal is handicapped by low domestic research and production capacity, which results in the poor supply of breeder and foundation seed for its multiplication. The production of breeder and foundation seed in Nepal was 31.7 and $429 \mathrm{Mt}$, but the demand was 340 and $3300 \mathrm{Mt}$, respectively, in 2009/2010 [8]. Improved seeds of maize cover 614,221 ha of land in the hills with the yield of $2.477 \mathrm{Mt} / \mathrm{ha}$. The total production is $1,521,311 \mathrm{Mt}$. In contrast, use of local seeds covers 62,350 ha of land with the production of $96,600 \mathrm{Mt}$ and the yield is $1.549 \mathrm{Mt} / \mathrm{ha}$ [9]. The yield from improved seeds is much better than local seeds. Improved better quality seeds contribute to about $20-30 \%$ increase in yield [10].

Production of foundation and certified seed requires intensive care and management. It should have high purity, with better germination and be viable quality seed. In most of the countries, certification of seed is mandatory [11]. The major hindrance for commercialization of seed production is small landholding with subsistence and mixed farming system [1]. Lack of availability of quality seed and high price of preferred varieties is detrimental to increase production [12]. About $40-45 \%$ of maize is imported annually to the country from India [13]. The available data on maize production show the increase in production was due to the increase in crop area rather than an increase in yield [1]. Farmers are attracted toward hybrid maize production due to the high demand for maize in poultry feed [14]. However, Government of Nepal does not have any record about the hybrid varieties and information on supply of improved seeds is very limited [15]. Maize has yielded more with the adoption of new technology, which has increased the maize production of small holder farmers [16]. Thus, seed is one of the most important inputs for increasing production and yield. Hence, it should be made easily available and used efficiently for the improvement of the livelihood and income of rural people.

\section{Objectives}

1. To assess the profitability of maize seed production.

2. To evaluate the determinants of foundation seed production and its income.

\section{Research methodology}

\section{Selection of study area}

Maize is considered as a staple crop in the hills of Nepal. The production of maize seed was found more in Palpa among other districts. Hence, Palpa District was selected for this study. The production of maize seed in this district is increasing and farmers adopt the recommended practices (key informant interview with Crop Development Officer of DADO, Palpa, June 2016). The district is one of the districts of Province No. 5 in western Nepal. It has a subtropical climate with an altitude ranging from 251 to $1943 \mathrm{~m}$ above sea level. Geographically, the district is situated at $27^{\circ} 52^{\prime}$ north latitude and $83^{\circ} 33^{\prime}$ east longitude. It is located at the mid-hills of Nepal.

\section{Sampling frame and sample size}

There were 8 farmers' groups and 3 cooperatives registered in Palpa District. These registered farmers' groups and cooperatives are comprised of 260 member farmers growing maize for seed purpose (DADO, Palpa). The sample size was determined using the software Raosoft at the 95\% confidence level, and a total of 182 samples were selected using simple random sampling technique. The sampled household was representative of the district (about 70\% representative). Among the total sampled households, there were 18 (10\%) and 164 (90\%) farmers involved in the production of foundation and certified seed, respectively. As the total sample is $70 \%$ representative of the study area, the study of profitability, adoption of foundation seed production and determinants of maize seed income reflects the situation of the district as a whole.

\section{Data collection}

The interview schedule was pretested among 10 respondents of Madanpokhara VDC of Palpa District. The necessary modification and corrections were done in the interview schedule before administering to actual respondents for the collection of primary data. Focus Group Discussion (FGD) and Key Informant Interview (KII) were done with the help of prepared interview schedule to triangulate data collected during face-face interview method. Secondary data were collected from the various governmental and non-governmental organizations. The field survey was carried out during June 2016.

\section{Methods and techniques of data analysis}

Data were entered in the SPSS software, and analysis was done using SPSS and Stata software. Work on cleaning and missing data was done to improve data quality. Descriptive statistics, mean comparison, probit model, income regression model and the instrumental variable model were used to derive the required result. 


\section{Cost of production}

The variable cost involved in maize seed production was categorized under six different headings.

Total variable cost of maize seed production

$$
=C_{\text {seed }}+C_{\mathrm{FYM}}+C_{\text {fert }}+C_{\text {tillage }}+C_{\text {labor }}+C_{\text {other }}
$$

where $C_{\text {seed }}$, is total cost of seed in NRs.; $C_{\mathrm{FYM}}$, total cost of farmyard manure (goat, cattle, buffalo and poultry manure) in NRs.; $C_{\text {fert }}$, total cost of chemical fertilizer (urea, DAP and potash) in NRs.; $C_{\text {labor }}$, total cost of labor used (land preparation, applying manure and fertilizer, planting, weeding, rouging, harvesting, post-harvest operation) in NRs.; $C_{\text {tillage }}$ total cost on tillage (tillage by bullock and tractor) in NRs.; $C_{\text {other }}$, total cost on management and other aspects (transportation, certification, inspection, celphos, bag) in NRs.

\section{Benefit-cost analysis}

The purpose to do benefit-cost analysis is to find the investment made on the resources will yield a reasonable return to the resources engaged. Benefit-cost ratio (BCR) is assumed as a quick and one of the easiest methods for evaluating the economic performance of any farm [3]. BCR compares the benefit per unit of cost. Thus, BCR was calculated by using the following formula:

$$
\mathrm{BCR}=\frac{\text { Total income (NRs.) }}{\text { Total variable cost (NRs.) }}
$$

where, total income is price of maize seed $x$ total amount of maize seed produced + equivalent amount of stovers and cone of maize seed; total variable cost is summation of cost incurred in the variable inputs.

\section{Econometric models Probit model}

In order to identify the determinants of adoption of foundation seed production, probit model was used. The probit model is predominantly used to identify factors influencing the adoption of agricultural practices [17]. The probit model includes believable error term distribution as well as realistic probabilities [18].

Let us suppose $Y_{i}$ is the binary response of the farmers; $Y_{i}=1$, if a farmer adopts the foundation seed production and $Y_{i}=0$ if a farmer adopts the certified seed production. This model was used to identify the determinants (regressors) on the probability of adoption of foundation seed production (regressand). LSU was computed to study the effect of total livestock holding of household based on the formula [19] ( 1 cattle/buffalo $=10$ goats $=4$ pigs $=143$ chicken/ducks).
Model specification:

$$
\begin{aligned}
\operatorname{Pr}(Y=1)= & f\left(b_{0}+b_{1} X_{1}+b_{2} X_{2}+b_{3} X_{3}+b_{4} X_{4}\right. \\
& +b_{5} X_{5}+b_{6} X_{6}+b_{7} X_{7}+b_{8} X_{8} \\
& \left.+b_{9} X_{9}+b_{10} X_{10}\right)
\end{aligned}
$$

where $\operatorname{Pr}(Y=1)$ is probability of adoption of foundation seed production; $X_{1}$, gender of household head (male $=1$, otherwise 0 ); $X_{2}$, education of household head (year); $X_{3}$, family type (joint $=1$, otherwise 0 ); $X_{4}$, economically active member in household (number); $X_{5}$, livestock holding calculated as Livestock Standard Unit (LSU); $X_{6}$, farm category (large scale $=1$, otherwise 0 ); $X_{7}$, income from maize seed production (natural log transformation); $X_{8}$, membership (cooperative $=1$, otherwise 0 ); $X_{9}$, training received (yes $=1$, otherwise 0 ); $X_{10}$, seed source [National Maize Research Program $(\mathrm{NMRP})=1$, otherwise 0$] ; b_{1}, b_{2} \ldots b_{10}$, probit coefficient; $b_{0}$, regression coefficient.

\section{Income regression model}

The total income from maize seed production was regressed with the important explanatory variables.

Model specification:

$$
\begin{aligned}
\operatorname{Ln}(Y)= & a+b_{1} X_{1}+b_{2} X_{2}+b_{3} X_{3}+b_{4} X_{4}+b_{5} X_{5}+b_{6} X_{6} \\
& +b_{7} X_{7}+b_{8} X_{8}+b_{9} X_{9}+b_{10} X_{10}+b_{11} X_{11}
\end{aligned}
$$

where $Y$ is natural $\log$ of total income from maize seed production (NRs.); $X_{1}$, gender of household head (male $=1$, otherwise 0 ); $X_{2}$, age of household head (year); $X_{3}$, education of household head (year); $X_{4}$, educated members in the household; $X_{5}$, maize seed area (hectare); $X_{6}$, livestock holding (LSU); $X_{7}$, seed production (foundation seed $=1$, otherwise 0 ); $X_{8}$, extension service (yes $=1$, otherwise 0 ); $X_{9}$, training (yes $=1$, otherwise 0 ); $X_{10}$, membership (cooperative $=1$, otherwise 0 ); $X_{11}$, migration (yes $=1$, otherwise 0 ); $a$, intercept; $b_{1}, b_{2} \ldots b_{10}$, coefficients for the respective variables.

Regression diagnostics:

The explanatory variables used in models were tested for multicollinearity through the estimation of Variance Inflation Factor (VIF). The VIF value of 10 is recommended as the maximum level.

\section{Instrumental variable model}

Adoption of foundation seed production and its contribution on income from the seed were correlated with each other. To combat such endogeneity problem, training received was used as an instrument in the instrumental variable model. The training received and income from maize seed were found to have positive and statistically significant association with the adoption of foundation seed production. 
Model specification:

$$
\begin{aligned}
\operatorname{Ln}(Y)= & a+b_{1} X_{1}+b_{2} X_{2}+b_{3} X_{3}+b_{4} X_{4}+b_{5} X_{5} \\
& +b_{6} X_{6}+b_{7} X_{7}+b_{8} X_{8}+b_{9} X_{9}+b_{10} X_{10}
\end{aligned}
$$

where $\operatorname{Ln}(Y)$ is natural $\log$ of total income from maize seed production (NRs.); $X_{1}$, gender of household head (male $=1$, otherwise 0 ); $X_{2}$, age of household head (year); $X_{3}$, education of household head (year); $X_{4}$, educated members in the household; $X_{5}$, maize seed area (hectare); $X_{6}$, livestock holding (LSU); $X_{7}$, seed production (foundation seed $=1$, otherwise 0 ); $X_{8}$, extension service (yes $=1$, otherwise 0 ); $X_{9}$, membership (cooperative $=1$, otherwise 0 ); $X_{10}$, migration (yes $=1$, otherwise $0) ; a$, intercept $b_{1}, b_{2} \ldots b_{10}$, coefficients for the respective variable.

\section{Results and discussion}

Among the major socioeconomic variables, experience in maize seed production and livestock holding (LSU) was found statistically significant at the $1 \%$ level of significance. Foundation seed production requires intensive care, skills and technical knowledge, so it needs more experience. As expected, the foundation seed producer had about 10 years of experience in seed production as compared to around 6 years among certified seed producers. It was expected that foundation seed producer had more livestock holdings in order to meet the recommended dose of farmyard manure (FYM). This will be crucial to produce a better quality seed as foundation seeds require a high germination and purity percentage than certified seed. Similarly, the livestock holding of foundation and certified seed producer was about $6 \mathrm{LSU}$ and $3 \mathrm{LSU}$, respectively. Similarly, the foundation seed producers had higher value for other socioeconomic variables such as age, education, household size, active members, educated members, total landholding, access to extension service and training received, compared to certified seed producer (Table 1). However, dependency ratio $^{1}$ and cultivated land were higher among the certified seed producers. The differences, however, were statistically non-significant.

\section{Description of important socioeconomic and demographic characteristics}

The variables such as training received, source of foundation and certified seed, and variety used were found statistically significant at either 1 or $5 \%$ level of significance (Table 2). About 89 and 68\% foundation seed and certified seed producer, respectively, had received trainings either on maize seed production technology or marketing

\footnotetext{
${ }^{1}$ Dependency ratio $=$ Dependent members/Economically active members [20].
}

or general maize grain production. The source of seed was National Maize Research Program (NMRP), Rampur, Chitwan, for the majority of foundation seed producer (61\%) and certified seed producer (50\%). The source of foundation seed was also NMRP for $50 \%$ of the farmers involved in maize seed production in Arghakhachi District, Nepal [7]. About 61\% of foundation seed producer and $82 \%$ of certified seed producer used the variety Manakamana-3 for production of seed. The study area was a male dominated society (74\%). Around $42 \%$ of the household had migrated members. The majority (nearly $40 \%$ ) were the members of farmer groups with closely 91\% household accessed to extension service. The average area under maize seed cultivation was 0.32 ha in the study area. Large scale was categorized as those farmers who had more than 0.32 ha of land under maize seed production and small scale as those having less than 0.32 ha of land under maize seed production. The majority of the foundation (61\%) and certified seed (56\%) producers were found operating at small scale.

\section{Cost of various inputs used in maize seed production}

The costs associated with the maize seed production were cost of seed, labor, FYM, chemical fertilizer, tillage and management/other. The cost for each of the cost items, which was calculated on a per hectare basis, was higher in the case of foundation seed production except management/other cost. A cost on seed per hectare for the foundation and certified seed was NRs. 2421 and NRs. 1836, the difference was significant at the $1 \%$ level of significance. The cost of labor and FYM used for foundation seed was NRs. 10,551 and 13,260 more than that of certified seed, and the difference was significant at the $1 \%$ level of significance. Similarly, the cost of chemical fertilizer for foundation seed production was higher than that for certified seed production by NRs. 1102 (Table 3). The difference was statistically significant at the $1 \%$ level of significance.

\section{Economic analysis of maize seed production}

The overall average production per household was $504 \mathrm{~kg}$ with B:C ratio of 0.98 in the study area. The overall yield, total income and profit from the maize seed production per hectare were $1636 \mathrm{~kg}$, NRs. 75,733 and NRs. -6739, respectively. The average production of foundation and certified seed was about 611 and $492 \mathrm{~kg}$ per household, respectively. The yield of foundation and certified seed was 2161 and $1579 \mathrm{~kg}$, respectively. The difference was found statistically significant at the $1 \%$ level of significance. The higher yield of foundation seed was mainly due to higher experience on seed production, access to training, source of seed from NMRP, variety used, more livestock holding and also due to intensive care during its production (Tables 1 and 2). The total cost for foundation 
Table 1 Description of socioeconomic and demographic characteristics (continuous variable) with seed production

\begin{tabular}{|c|c|c|c|c|c|}
\hline \multirow[t]{2}{*}{ Variables } & \multirow[t]{2}{*}{ Overall } & \multicolumn{2}{|l|}{ Seed production } & \multirow[t]{2}{*}{ Mean difference } & \multirow[t]{2}{*}{$p$ value } \\
\hline & & Foundation seed & Certified seed & & \\
\hline Age of $\mathrm{HHH}$ & $56.77(14.30)$ & $58.33(14.02)$ & $56.60(14.36)$ & 1.73 & 0.627 \\
\hline Education of $\mathrm{HHH}$ & $5.51(4.69)$ & $6.00(5.16)$ & $5.45(4.65)$ & 0.55 & 0.639 \\
\hline Experience & $6.63(3.91)$ & $10.33(3.50)$ & $6.20(3.74)$ & $4.11^{* * *}$ & 0.000 \\
\hline Household size & $5.41(2.72)$ & $5.67(3.24)$ & $5.38(2.67)$ & 0.29 & 0.670 \\
\hline Active members & $3.59(2.21)$ & $3.89(2.59)$ & $3.56(2.17)$ & 0.33 & 0.552 \\
\hline Dependency ratio & $0.62(0.62)$ & $0.42(0.36)$ & $0.64(0.64)$ & -0.21 & 0.202 \\
\hline Educated members & $4.80(2.49)$ & $5.06(2.84)$ & $4.77(2.46)$ & 0.29 & 0.643 \\
\hline Total landholding (ha) & $0.91(0.79)$ & $0.94(0.71)$ & $0.91(0.80)$ & 0.04 & 0.854 \\
\hline Cultivated land (ha) & $0.49(0.36)$ & $0.48(0.31)$ & $0.50(0.37)$ & -0.02 & 0.893 \\
\hline Maize seed area (ha) & $0.32(0.17)$ & $0.32(0.18)$ & $0.32(0.17)$ & 0.00 & 0.926 \\
\hline Livestock holding (LSU) & $3.05(5.63)$ & $6.27(8.54)$ & $2.69(5.13)$ & $3.58^{* * *}$ & 0.010 \\
\hline Training received & $2.09(1.26)$ & $2.50(1.03)$ & $2.04(1.28)$ & 0.46 & 0.168 \\
\hline Extension service & $1.79(0.29)$ & $1.83(0.92)$ & $1.79(0.56)$ & 0.04 & 0.773 \\
\hline
\end{tabular}

Figures in parentheses indicate standard deviation

*** Indicates significant at the $1 \%$ level of significance. $p$ values are the result of $t$ test

seed production (NRs. 106,205) was higher as compared to certified seed production (NRs. 79,868). The difference was statistically significant at the $1 \%$ level of significance. The total cost for foundation seed production was higher because it requires intensive care and management. The income from foundation seed (NRs. 122,177) was significantly higher as compared to certified seed production (NRs. 70,636). The income of foundation seed producers was higher by more than NRs. 51,000 as the selling price of foundation seed was higher (NRs. 85 in the case of foundation seed vs. NRs. 59 in case of certified seed) and the yield was also higher. The profit from foundation seed was NRs. 15,971, whereas there was a loss of NRs. 9232 from certified seed production. The difference was found statistically significant at the $1 \%$ level of significance. The benefit-cost ratio of foundation and certified seed production was 1.16 and 0.96 , respectively, and the difference was found statistically significant (Table 4). This revealed that foundation seed production was a profitable business. There was a practice of applying FYM at the time of land preparation for maize seed cultivation. This FYM was also targeted for other crops grown in a same cropping year. Hence, the calculation of total cost that includes the cost of entire FYM as well as family labor in transporting the FYM to the field had resulted in a low benefit-cost ratio.

\section{Determinants of adoption of foundation seed production using probit model}

Household income increases with the adoption of foundation seed production as its price is higher as compared to certified seed production. So, probit model was used to identify the determinants of adoption of foundation seed production. The likelihood ratio Chi-square (LR $\mathrm{chi}^{2}$ ) for the model was statistically significant at the $1 \%$ level of significance (Table 5), which revealed the model has good explanatory power.

The explanatory variables such as education of household head, family type, active members, farm category, income and training received were major influencing factors for the adoption of foundation seed production. If the education of $\mathrm{HHH}$ increased by 1 year, then the probability of adopting foundation seed production would decrease by about $0.4 \%$ which was statistically significant (Table 5). This revealed that those who were educated gets involve in certified seed production. If the household had joint family type, the probability of adoption of foundation seed production would decrease by about $6 \%$. The relation was statistically significant at the $5 \%$ level of significance. With an increase in the economically active member, the probability of adopting foundation seed production would increase by about $1 \%$ and was statistically significant at the $10 \%$ level of significance. Active members are energetic and they adopt new technology and practices, so it has a positive effect. The positive effect of active members on the adoption of sustainable soil management practice (SSMP) was also found [21]. If the farmers would be able to allocate the large area under maize seed cultivation, the probability of adopting foundation seed production would increase by about $4 \%$. Similarly, if the farmers received more income per hectare from maize seed production, 
Table 2 Description of socioeconomic, demographic and institutional characteristics (categorical variables) with seed production

\begin{tabular}{|c|c|c|c|c|c|}
\hline \multirow[t]{2}{*}{ Variables } & \multirow[t]{2}{*}{ Overall } & \multicolumn{2}{|l|}{ Seed production } & \multirow[t]{2}{*}{ Chi-square value } & \multirow[t]{2}{*}{$p$ value } \\
\hline & & Foundation seed & Certified seed & & \\
\hline \multicolumn{6}{|l|}{ Gender of $\mathrm{HHH}$} \\
\hline Male & $135(74.2)$ & $16(88.9)$ & $119(72.6)$ & 2.257 & 0.133 \\
\hline Female & $47(25.8)$ & $2(11.1)$ & $45(27.4)$ & & \\
\hline \multicolumn{6}{|l|}{ Family type } \\
\hline Joint & $92(50.5)$ & $7(38.9)$ & $85(51.8)$ & 1.087 & 0.297 \\
\hline Nuclear & $90(49.5)$ & $11(61.1)$ & $79(48.2)$ & & \\
\hline \multicolumn{6}{|l|}{ Migration } \\
\hline Yes & $77(42.3)$ & $7(38.9)$ & $70(42.7)$ & 0.096 & 0.757 \\
\hline No & $105(57.7)$ & $11(61.1)$ & $94(57.3)$ & & \\
\hline \multicolumn{6}{|c|}{ Membership in social groups } \\
\hline Farmer group & $72(39.6)$ & $7(38.9)$ & 65 (39.6) & 0.071 & 0.965 \\
\hline Cooperative & $46(25.3)$ & $5(27.8)$ & $41(25.0)$ & & \\
\hline Both & $64(35.2)$ & $6(33.3)$ & $58(35.0)$ & & \\
\hline \multicolumn{6}{|l|}{ Training received } \\
\hline Yes & $127(69.8)$ & $16(88.9)$ & $111(67.7)$ & $3.459^{*}$ & 0.063 \\
\hline No & $55(30.2)$ & $2(11.1)$ & $53(32.3)$ & & \\
\hline \multicolumn{6}{|c|}{ Access to extension service } \\
\hline Yes & $165(90.7)$ & $18(100.0)$ & $147(89.6)$ & 2.058 & 0.151 \\
\hline No & $17(9.3)$ & $0(0.0)$ & $17(10.4)$ & & \\
\hline \multicolumn{6}{|l|}{ Access to credit } \\
\hline Easy & $149(81.9)$ & $14(77.8)$ & $135(82.3)$ & 0.225 & 0.635 \\
\hline Satisfactory & $33(18.1)$ & $4(22.2)$ & $29(17.7)$ & & \\
\hline \multicolumn{6}{|l|}{ Source of seed } \\
\hline DADO & $62(34.1)$ & $0(0.0)$ & $62(37.8)$ & $14.987^{* * *}$ & 0.001 \\
\hline NMRP & $93(51.1)$ & $11(61.1)$ & $82(50.0)$ & & \\
\hline LAC & $27(14.8)$ & 7 (38.9) & $20(12.2)$ & & \\
\hline \multicolumn{6}{|l|}{ Variety } \\
\hline Manakamana-3 & $146(80.2)$ & $11(61.1)$ & $135(82.3)$ & $5.495^{*}$ & 0.064 \\
\hline Manakamana-6 & 34 (18.7) & $7(38.9)$ & $27(16.5)$ & & \\
\hline Both & $2(1.1)$ & $0(0.0)$ & $2(1.2)$ & & \\
\hline \multicolumn{6}{|l|}{ Farm category } \\
\hline Large scale & $71(39.0)$ & $8(44.4)$ & $63(38.4)$ & 0.248 & 0.619 \\
\hline Small scale & $111(61.0)$ & $10(55.6)$ & $101(61.6)$ & & \\
\hline
\end{tabular}

Figures in parentheses indicate percent

***, * Indicate significant at the $1 \%$ and $10 \%$ level of significance, respectively. $p$ values are the result of the Chi-square test

the probability of adoption of the foundation seed production would increase by about $11 \%$ which was statistically significant at the $1 \%$ level of significance. Farmers can generate more income from the sale of foundation seed as its price as well as the yield was higher as compared to certified seed. If farmer received training on maize seed production technology or marketing, then the probability of adopting foundation seed production would increase by $4.6 \%$ as compared to the nonreceivers (Table 5). This might be due to the fact that the farmer gains high skills and knowledge through training. Hence, get motivated to adopt the new technology.
The previous finding also showed that the farmers who received training would adopt SSMP by $73.5 \%$ and was highly significant [21]. The positive relationship between training received and adoption of organic fertilizers as well as on the intensity of use of improved yam seed technology was also noted [22, 23]. The other variables such as gender of $\mathrm{HHH}$ and livestock holding (LSU) influence positively. However, the dummies for membership in cooperative and seed source from NMRP on the adoption of foundation seed production showed the negative association though they were statistically non-significant. 
Table 3 Cost of various inputs used in maize seed production

\begin{tabular}{|c|c|c|c|c|c|}
\hline \multirow[t]{2}{*}{ Variables } & \multirow[t]{2}{*}{ Overall } & \multicolumn{2}{|l|}{ Seed production } & \multirow[t]{2}{*}{ Mean difference } & \multirow[t]{2}{*}{$p$ value } \\
\hline & & Foundation seed & Certified seed & & \\
\hline Seed & $1893.92(724.09)$ & $2420.72(849.42)$ & $1836.10(687.71)$ & $584.62^{* * *}$ & 0.001 \\
\hline Labor & $45,048.04(20,092.25)$ & $54,555.33(22,180.66)$ & $44,004.55(19,644.09)$ & $10,550.77^{* *}$ & 0.034 \\
\hline FYM & $23,368.44(19,869.21)$ & $35,317.08(20,017.81)$ & $22,057.00(19,470.30)$ & $13,260.07^{* * *}$ & 0.007 \\
\hline Chemical fertilizer & $1657.70(1430.81)$ & 2650.47 (1481.39) & 1548.74 (1386.95) & $1101.73^{* * *}$ & 0.002 \\
\hline Tillage & $10,021.96(6189.28)$ & 10,788.67 (4233.96) & 9937.81 (6371.48) & 850.86 & 0.581 \\
\hline Management/other & $482.45(700.98)$ & $473.13(313.38)$ & $483.47(731.70)$ & -10.34 & 0.953 \\
\hline
\end{tabular}

Figures in parentheses indicate standard deviation

***,** Indicate significant at the $1 \%$ and $5 \%$ level of significance, respectively. $p$ values are the result of $t$ test

Table 4 Economic analysis of maize seed production (in hectare)

\begin{tabular}{|c|c|c|c|c|c|}
\hline \multirow[t]{2}{*}{ Variables } & \multirow[t]{2}{*}{ Overall } & \multicolumn{2}{|l|}{ Seed production } & \multirow[t]{2}{*}{ Mean difference } & \multirow[t]{2}{*}{$p$ value } \\
\hline & & Foundation seed & Certified seed & & \\
\hline Production $(\mathrm{kg} / \mathrm{HH})$ & $503.77(398.89)$ & $610.56(382.29)$ & $492.05(400.06)$ & 118.50 & 0.233 \\
\hline Yield (kg) & $1636.11(749.97)$ & 2160.61 (1008.93) & 1578.54 (696.19) & $582.06^{* * *}$ & 0.002 \\
\hline Total cost (NRs.) & $82,472.51(38,808.03)$ & $106,205.40(35,022.81)$ & $79,867.68(38,411.24)$ & $26,337.72^{* * *}$ & 0.006 \\
\hline Income (NRs.) & $75,733.07(38,151.50)$ & $122,176.63(55,350.66)$ & $70,635.61(32,131.15)$ & $51,541.02^{* * *}$ & 0.000 \\
\hline Profit (NRs.) & $-6739.44(38,505.01)$ & $15,971.23(43,703.80)$ & -9232.07 (37,201.47) & $25,203.30^{* * *}$ & 0.008 \\
\hline $\mathrm{B}: \mathrm{C}$ ratio & $0.98(0.43)$ & $1.16(0.37)$ & $0.96(0.44)$ & $0.19^{*}$ & 0.073 \\
\hline
\end{tabular}

Figures in parentheses indicate standard deviation

***, ${ }^{*}$ Indicate significant at the $1 \%$ and $10 \%$ level of significance, respectively. $p$ values are the result of $t$ test

\section{Determinants of income from maize seed using the income regression model}

The value of $R^{2}$ indicates that around $61 \%$ of the variations in income from maize seed was explained by the explanatory variables in the model. The value of adjusted $R^{2}$ indicates that when the degree of freedom is taken into account, about $58 \%$ of the variations in the dependent variable (income) is explained by explanatory variables in the model. The statistically significant $F$ value implies that the explanatory variables included in the model are important for the explanation of the variation in the dependent variable. The mean VIF was 1.19 , which is less than the recommended VIF value of 10 as the maximum level. Thus, multicollinearity in the selected model is significantly low.

With respect to age, increase in age of $\mathrm{HHH}$ by 1 year, the income from maize seed production increases by $0.6 \%$, which was statistically significant at the $5 \%$ level of significance (Table 6). It was expected that the increase in age of household head means an increase in experience. Hence, more experienced people would use their knowledge and idea wisely to increase production, therefore income, from maize seed production. Similarly, 1 year increase in the education of the $\mathrm{HHH}$ would increase the income by $1.5 \%$ and was found statistically significant at the $10 \%$ level of significance. The more year of schooling means more education and knowledge so that they can apply in their practical life and help to increase the income. As the educated member in $\mathrm{HH}$ goes up by one unit, the income would increase by $3 \%$ which was statistically significant. As the involvement of household members is more in agriculture, increase in the education level of household member would adopt better management practices and increase the income. With an increase in the maize seed area by one unit (hectare), income would increase by about $242 \%$, which was found highly significant at the $1 \%$ level of significance. Production would be more from larger area which would ultimately increase the income. Those farmers involved in the production of foundation seed, their income would increase by about $44 \%$ as compared to those who were involved in certified seed production and was statistically significant at the $1 \%$ level of significance. The price of foundation seed was more than that of certified seed, so farmer's income would increase more if they involved in the production of foundation seed.

For those farmers who had received extension services, their income would increase by about $24 \%$ as compared 
Table 5 Determinants of adoption of foundation seed production using probit model

\begin{tabular}{|c|c|c|c|c|}
\hline Variables & Coefficients & Standard error & $p$ value & $d y / d x$ \\
\hline Gender of $\mathrm{HHH}^{\mathrm{a}}$ & 0.591 & 0.498 & 0.235 & 0.027 \\
\hline $\begin{array}{l}\text { Education of } \mathrm{HHH} \\
\text { (year) }\end{array}$ & $-0.069^{*}$ & 0.042 & 0.097 & -0.004 \\
\hline Family type ${ }^{a}$ & $-0.902^{* *}$ & 0.430 & 0.036 & -0.059 \\
\hline Active members & $0.156^{*}$ & 0.083 & 0.058 & 0.009 \\
\hline $\begin{array}{l}\text { Livestock holding } \\
\text { (LSU) }\end{array}$ & 0.033 & 0.021 & 0.121 & 0.002 \\
\hline Farm category & $0.593^{*}$ & 0.357 & 0.096 & 0.041 \\
\hline log Income (NRs.) & $1.792^{* * *}$ & 0.437 & 0.000 & 0.106 \\
\hline $\begin{array}{l}\text { Membership in } \\
\text { cooperative }^{\mathrm{a}}\end{array}$ & -0.246 & 0.412 & 0.551 & -0.015 \\
\hline Training $^{\mathrm{a}}$ & $1.023^{* *}$ & 0.496 & 0.039 & 0.046 \\
\hline $\begin{array}{l}\text { Seed source from } \\
\text { NMRP }^{a}\end{array}$ & -0.023 & 0.414 & 0.956 & -0.001 \\
\hline Constant & $-22.922^{* * *}$ & 5.140 & 0.000 & \\
\hline Observations & 182 & & & \\
\hline Log likelihood & -39.4317 & & & \\
\hline LR chi ${ }^{2}(10)$ & $38.59^{* * *}$ & & & \\
\hline Prob > chi ${ }^{2}$ & 0.000 & & & \\
\hline Pseudo $R^{2}$ & 0.3285 & & & \\
\hline
\end{tabular}

$* * * * *,{ }^{*}$ Indicate significant at the 1,5 and $10 \%$ level of significance, respectively

a Indicates a dummy variable

to those who did not receive and was found statistically significant at the $5 \%$ level of significance. Access to extension service helps to increase the technical knowledge and information about better practices. Similarly, those who were the members of cooperatives, their income would increase by about $15 \%$ as compared to those who were member of farmer groups and found statistically significant at the $5 \%$ level of significance. The cooperative is supposed to have more capital and is a circle of more people and can be said big organization as compared to farmer groups and organizes various programs at district or even the regional level to increase the knowledge of farmers. For those households who had migrated member, their income would decrease by about $26 \%$ as compared to those who did not have migrated member. The relationship was statistically significant at the $1 \%$ level of significance. Migration of the member from household creates the shortage of labor. As agricultural practice is more laborious, labor is the active factor in factors of production which is an important in determining production and income. It was reported that land size, extension visit and membership in cooperatives influence the profitability of maize seed significantly in Zamfara State, Nigeria [24]. Similarly, it was also noted that the extension visit and membership in a farmer's association had a positive effect on farmer's profit among the small-scale maize seed in west and central Africa [25].
Table 6 Determinants of income from maize seed production

\begin{tabular}{|c|c|c|c|c|}
\hline Variables & Coefficients & Standard error & $t$ value & $p$ value \\
\hline Gender of $\mathrm{HHH}^{\mathrm{a}}$ & 0.007 & 0.081 & 0.08 & 0.934 \\
\hline Age of $\mathrm{HHH}$ (year) & $0.006^{* *}$ & 0.003 & 2.04 & 0.043 \\
\hline $\begin{array}{l}\text { Education of } \mathrm{HHH} \\
\text { (year) }\end{array}$ & $0.015^{*}$ & 0.009 & 1.71 & 0.089 \\
\hline $\begin{array}{l}\text { Educated member } \\
\text { in } \mathrm{HH}\end{array}$ & $0.030^{* *}$ & 0.013 & 2.25 & 0.026 \\
\hline Maize area (hectare) & $2.423^{* * *}$ & 0.193 & 12.57 & 0.000 \\
\hline $\begin{array}{l}\text { Livestock holding } \\
\text { (LSU) }\end{array}$ & 0.004 & 0.006 & 0.7 & 0.482 \\
\hline $\begin{array}{l}\text { Foundation seed } \\
\text { production }^{\mathrm{a}}\end{array}$ & $0.441^{* * *}$ & 0.111 & 3.96 & 0.000 \\
\hline Extension service ${ }^{a}$ & $0.238^{* *}$ & 0.119 & 1.99 & 0.048 \\
\hline Training received ${ }^{a}$ & -0.017 & 0.074 & -0.23 & 0.815 \\
\hline $\begin{array}{l}\text { Membership in } \\
\text { cooperative }^{\mathrm{a}}\end{array}$ & $0.146^{* *}$ & 0.068 & 2.14 & 0.034 \\
\hline Migration $^{\mathrm{a}}$ & $-0.263^{* * *}$ & 0.069 & -3.81 & 0.000 \\
\hline Constant & $8.278^{* * *}$ & 0.22 & 37.68 & 0.000 \\
\hline Observations & 182 & & & \\
\hline$F(11,170)$ & $23.87^{* * *}$ & & & \\
\hline$R^{2}$ & 0.607 & & & \\
\hline $\operatorname{Adj} R^{2}$ & 0.582 & & & \\
\hline
\end{tabular}

$* * *, * * *$ Indicate significant at the 1,5 and $10 \%$ level of significance, respectively

${ }^{a}$ Indicates a dummy variable

The other explanatory variables such as gender of household head, livestock holding (LSU) and training received were statistically non-significant.

\section{Effect on maize seed income using the instrumental variable model}

During the analysis, it was found that the income from maize seed and training received had positive and statistically significant effect on the adoption of foundation seed production. Adoption of foundation seed production had positive and statistically significant effect on income from maize seed production. To combat such endogeneity, the instrumental variable model was used. Hence, the adoption of foundation seed production (as a dummy) was instrumented and the variable training received was used as an instrumental variable. The highly significant $F$ value indicates that the selection of explanatory variables in the model was enough to describe the variation in the dependent variable. About $60 \%$ variation in the dependent variable was explained by the explanatory variable (Table 7 ). In the instrumental variable model, the production of foundation seed had a positive effect, but it was statistically non-significant. This revealed that actually the production of foundation seed does not have a significant effect on income of farmers in the study area. 
Table 7 Effect on income using the instrumental variable model

\begin{tabular}{|c|c|c|c|c|}
\hline Variables & Coefficients & Standard error & $t$ value & $p$ value \\
\hline Gender of $\mathrm{HHH}^{\mathrm{a}}$ & 0.019 & 0.097 & 0.190 & 0.849 \\
\hline Age of HHH (year) & $0.006^{* *}$ & 0.003 & 2.010 & 0.046 \\
\hline $\begin{array}{l}\text { Education of } \mathrm{HHH} \\
\text { (year) }\end{array}$ & $0.015^{*}$ & 0.009 & 1.720 & 0.088 \\
\hline Educated members & $0.031^{* *}$ & 0.014 & 2.200 & 0.029 \\
\hline Maize area (hectare) & $2.403^{* * *}$ & 0.211 & 11.380 & 0.000 \\
\hline $\begin{array}{l}\text { Livestock holding } \\
\text { (LSU) }\end{array}$ & 0.006 & 0.011 & 0.570 & 0.569 \\
\hline $\begin{array}{l}\text { Foundation seed } \\
\text { production }^{\mathrm{a}}\end{array}$ & 0.206 & 1.006 & 0.210 & 0.838 \\
\hline Extension service ${ }^{a}$ & 0.255 & 0.157 & 1.620 & 0.106 \\
\hline $\begin{array}{l}\text { Membership in } \\
\text { cooperative }\end{array}$ & $0.146^{* *}$ & 0.069 & 2.110 & 0.036 \\
\hline Migration $^{\mathrm{a}}$ & $-0.264^{* * *}$ & 0.070 & -3.790 & 0.000 \\
\hline Constant & $8.246^{* * *}$ & 0.246 & 33.560 & 0.000 \\
\hline Observations & 182 & & & \\
\hline$F(10,171)$ & $24.20^{* * *}$ & & & \\
\hline$R^{2}$ & 0.5968 & & & \\
\hline $\operatorname{Adj} R^{2}$ & 0.5732 & & & \\
\hline Instrumented & Foundation s & seed production (c & dummy) & \\
\hline
\end{tabular}

***,**** Indicate significant at the 1,5 and $10 \%$ level of significance, respectively

a Indicates a dummy variable

\section{Conclusion}

The study revealed that the foundation seed producer had more year of experience in maize seed production. The livestock holding (LSU) was also higher in the case of foundation seed producer. The source of seed, variety used and training received about maize seed production technology was significantly different between the foundation and certified seed producer. The income from foundation seed production was more than about NRs. 51,000 with B:C ratio 1.16 as compared to certified seed. The low B:C ratio 0.96 of certified seed indicates that the certified seed production in the study area was at a loss. The major determinants of adoption of foundation seed production were income from maize seed production, training received and type of family. Production of foundation seed would increase the income of maize seed positively and significantly by about $44 \%$. The major determinants of income from maize seed production were maize seed area, foundation seed production, $\mathrm{HH}$ migration status, extension service and membership in cooperative. To address the endogeneity problem, the instrumental variable model was used and found the major determinants as maize seed area, membership in cooperative and migration to influence maize seed income. The production of foundation seed and extension received were found non-significant on the total income from maize seed production. The foundation seed production was profitable in the study area. So proper trainings and extension service is needed to aware and motivate the farmers to adopt the foundation seed production which could uplift their economic condition. Similarly, farmers can increase their area through contract and cooperative farming.

\begin{abstract}
Abbreviations
\%: percent; \&: and; ABPSD: Agribusiness Promotion and Statistics Division; AFU: Agriculture and Forestry University; AGDP: Agriculture Gross Domestic Product; AICC: Agriculture Information and Communication Centre; B:C: Benefit-cost; DADO: District Agriculture Development Office; FAO: Food and Agriculture Organization; FGD: Focus Group Discussion; FYM: farmyard manure; GDP: Gross Domestic Product; HHH: household head; IFPRI: International Food Policy Research Institute; KII: Key Informant Interview; LAC: Lumle Agriculture Centre; LSU: Livestock Standard Unit; MoAC: Ministry of Agriculture and Cooperatives; MoAD: Ministry of Agricultural Development; Mt: metric tonnes; NMRP: National Maize Research Program; NRs.: Nepali rupees; SPSS: Statistical Packages for Social Sciences; SQCC: Seed Quality Control Centre; SSMP: Sustainable Soil Management Practices; VDC: Village Development Committee; VIF: Variance Inflation Factor.
\end{abstract}

\section{Authors' contributions}

MS is the principal researcher, has conducted preliminary surveys, interview schedule design, pretesting, data collection, data entry, analysis, writing and manuscript preparation and drafted the manuscript. NPJ is an advisor of this study. He has guided MS while undertaking this research from the very beginning of this study. He provided guidance in finalization of questionnaire for the interview schedule and data analysis and revised manuscript minutely with critical comments and suggestions. RRK is also an advisor of this study. He has guided in designing the interview schedule, plan to collect data, helped in analysis of data, writing and has revised this manuscript with fruitful comments and suggestions. MB has assisted during preparation of the interview schedule, collecting data, data entry and manuscript preparation and revised this manuscript with practical comments and suggestions. All authors read and approved the final manuscript.

\section{Author details \\ ${ }^{1}$ Nepal Agricultural Research Council, Communication, Publication and Docu- mentation Division, Pilot Program for Climate Resilience, Khumaltar, Lalitpur, Nepal. ${ }^{2}$ Taoyako Program, Graduate School for International Development and Cooperation, Hiroshima University, Hiroshima, Japan. ${ }^{3}$ Department of Agricultural Economics and Agribusiness Management, Agriculture and For- estry University, Chitwan, Nepal. ${ }^{4}$ Ministry of Agricultural Development, District Agriculture Development Office, Baglung, Nepal.}

\section{Acknowledgements}

We would like to express our gratitude to Agriculture and Forestry University (AFU), Rampur, Chitwan, Nepal, for providing the favorable environment for this study. We would like to acknowledge our colleagues for their direct and indirect support to accomplish this research. We like to provide special thanks to Vivek Bista, Dhiraj Bhatta and Aavash Adhikari for their help and management during data collection. We are grateful to the respondents of Palpa District for providing reliable data despite their busy schedule.

\section{Competing interests}

The authors declare that they have no competing interests.

\section{Availability of data and materials}

The datasets used and analyzed during the current study are available from the corresponding author on reasonable request.

\section{Consent for publication}

A verbal consent for publication has been received from the participants of the interview schedule, FGD and KIl under the condition of anonymity, which was strictly maintained in this research paper. 


\section{Funding}

This study was supported partially by Directorate of Research and Extension, AFU.

\section{Publisher's Note}

Springer Nature remains neutral with regard to jurisdictional claims in published maps and institutional affiliations.

Received: 11 January 2017 Accepted: 19 April 2017

Published online: 15 May 2017

\section{References}

1. MoAD. Nepal portfolio performance review (NPPR). Ministry of Agricultural Development, Singhadurbar, Kathmandu; 2015.

2. AICC. Krishi diary. Agriculture Information Communication Centre. Ministry of Agricultural Development, Department of Agriculture, Hariharbhawan, Lalitpur; 2016.

3. Dhakal SC, Regmi PP, Thapa RB, Sah SK, Khatri-Chhetri DB. Productivity and profitability of maize-pumpkin mix cropping in Chitwan, Nepal. J Maize Res Dev. 2015;1(1):112-22.

4. Bahadur KCD, Gadal N, Neupane SP, Puri RR, Khatiwada B, Ortiz-Ferrara G, Sadananda AR, Bober C. Maize seed marketing chains and marketing efficiency along supply chains of the hills in Nepal. Int J Agric Mark. 2015:2(1):026-33. ISSN: 2167-0470.

5. Tsegaye D. Profitability of contractual bread wheat seed production in Mecha district of Amhara region, Ethiopia. J Cent Eur Agric. 2012;13(1):142-9.

6. Langyintuo AS. Maize production systems for Zimbabwe: Setting indicators for impact assessment and targeting. In: Research project on strengthening seed marketing incentives in southern Africa to increase impact of maize breeding. International Maize and wheat improvement centre (CIMMYT), Harare; 2005.

7. Bajracharya M, Sapkota M, Dhungana SM. Socio-economic analysis of maize seed production in Arghakhanchi district of Nepal. J Maize Res Dev. 2016:2(1):144-50.

8. MoAC. Nepal agriculture and food security country investment plan. Ministry of Agriculture and Cooperatives, Draft, Kathmandu; 2010

9. ABPSD. Statistical information on Nepalese agriculture 2013/2014. Agribusiness promotion and statistics division, statistics section. Government of Nepal, Ministry of Agricultural Development, Singha Durbar, Kathmandu; 2014.

10. SQCC. National seed vision 2013-2025, Seed sector development strategy. Government of Nepal, Ministry of Agricultural Development, National Seed Board, Seed Quality Control Centre, Hariharbhawan, Lalitpur; 2013.

11. Setimela PS, Mhike X, MacRobert JF, Muungani D. Maize hybrids and open-pollinated varieties: seed production strategies. Strategies for strengthening and scaling up community-based seed production. Mexico, CIMMYT; 2006.
12. Sapkota M, Dutta JP, Dhungana SM, Bajracharya M. Socioeconomic characteristics and status of cereal producer in Arghakhachi district of Nepal. Int J Agric Environ Res. 2016;2(4):768-76.

13. Bhattarai TC. Recent demand and supply situation of raw materials for the feed industries in Nepal. Paper presented in mission TST training in Chitwan, 2068; 2011.

14. IFPRI. Ensuring food and nutritional security in Nepal: a stocktaking exercise. International Food Policy Research Institute, Kathmandu, Nepal: USAID; 2010.

15. Pullabhotla H, Shreedhar G, Kumar AG, Gulati A. A review of input and output policies for cereal production in Nepal. Report prepared for the Cereals System Initiative for South Asia (CSISA), Discussion Paper, 1114; 2011.

16. Kibaara BW. Technical efficiency in Kenyan's maize production: an application of the stochastic frontier approach. M.Sc. Thesis, Department of Agricultural and Resource Economics, Colorado State University, Fort Collins; 2005.

17. Hattam C. Adopting organic agriculture: An investigation using the theory of planned behavior. Poster paper prepared for presentation, International Association of Agriculture Economics Conference, Gold Coast; 2006.

18. Nagler J. Interpreting probit analysis. New York University. 1994. http:// www.nyu.edu/classes/nagler/quant2/notes/probit1.pdf.

19. Kattel RR. Rainwater harvesting and rural livelihoods in Nepal. South Asian Network for Development and Environmental Economics (SANDEE). SANDEE Working Papers, ISSN 1893 1891; WP 102-15; 2015.

20. CBS. Population monograph of Nepal. Government of Nepal, National Planning Commission Secretariat, Central Bureau of Statistics, Ramshah Path, Kathmandu; 2014

21. Dhakal S. Assessment of climate smart sustainable soil management practices and their impact on farmers livelihood in Khotang, Nepal. M.Sc. Thesis Submitted to Agriculture and Forestry University, Rampur, Chitwan; 2015.

22. Nchinda VP, Ambe TE, Holvoet N, Leke W, Che MA, Nkwate SP, Ngassam SB, Njualem DK. Factors influencing the adoption intensity of improved yam (Dioscorea spp.) seed technology in the western highlands and high guinea savannah zones of Cameroon. J Appl Biosci. 2010;36:2389-402.

23. Nkamleu GB. Modeling farmers' decisions on integrated soil nutrient management in sub-Saharan Africa: a multinomial logit analysis in Cameroon. In: Advances in integrated soil fertility management in subSaharan Africa: challenges and opportunities. Springer, New York; 2007. pp. 891-904.

24. Umar S, Sanni SA, Usman IS, Shuaibu H. Community maize seed production as an income generating activity for poverty alleviation in selected communities of Zamfara state, Nigeria. In: Proceeding of the conference of Dryland; 2014.

25. Awotide DO, Tontsa HM. Small-scale maize seed production in west and central Africa: profitability, constraints and options. ICBE-RF Research Report No. 21/11; 2011.

\section{Submit your next manuscript to BioMed Central} and we will help you at every step:

- We accept pre-submission inquiries

- Our selector tool helps you to find the most relevant journal

- We provide round the clock customer support

- Convenient online submission

- Thorough peer review

- Inclusion in PubMed and all major indexing services

- Maximum visibility for your research

Submit your manuscript at

www.biomedcentral.com/submit

Biomed Central 